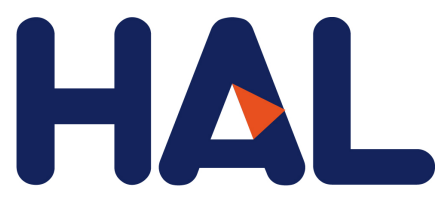

archives-ouvertes

\title{
Insights into the regulation of nitrogen fixation in pea nodules: lessons from drought, abscisic acid and increased photoassimilate availability
}

Esther González, Loli Gálvez, Mercedes Royuela, Pedro Aparicio-Tejo, Cesar Arrese-Igor

\section{To cite this version:}

Esther González, Loli Gálvez, Mercedes Royuela, Pedro Aparicio-Tejo, Cesar Arrese-Igor. Insights into the regulation of nitrogen fixation in pea nodules: lessons from drought, abscisic acid and increased photoassimilate availability. Agronomie, EDP Sciences, 2001, 21 (6-7), pp.607-613. 10.1051/agro:2001151 . hal-00886154

\section{HAL Id: hal-00886154 \\ https://hal.archives-ouvertes.fr/hal-00886154}

Submitted on 1 Jan 2001

HAL is a multi-disciplinary open access archive for the deposit and dissemination of scientific research documents, whether they are published or not. The documents may come from teaching and research institutions in France or abroad, or from public or private research centers.
L'archive ouverte pluridisciplinaire HAL, est destinée au dépôt et à la diffusion de documents scientifiques de niveau recherche, publiés ou non, émanant des établissements d'enseignement et de recherche français ou étrangers, des laboratoires publics ou privés. 


\title{
Insights into the regulation of nitrogen fixation in pea nodules: lessons from drought, abscisic acid and increased photoassimilate availability
}

\author{
Esther M. GonzÁlez, Loli Gálvez, Mercedes Royuela, \\ Pedro M. Aparicio-Tejo, Cesar Arrese-IGoR* \\ Department of Environmental Sciences, Universidad Pública de Navarra, Campus de Arrosadia, 31006 Pamplona, Spain
}

(Received 16 November 2000; revised 3 August 2001; accepted 22 August 2001)

\begin{abstract}
Nitrogen fixation in legume nodules has been shown to be very sensitive to drought and other environmental constraints. It has been widely assumed that this decline in nitrogen fixation was a consequence of an increase in the so-called oxygen diffusion barrier and a subsequent impairment to bacteroid respiration. However, it has been recently shown that nitrogen fixation is highly correlated with nodule sucrose synthase (SS) activity under drought and other environmental stresses. Whether this correlation reflects a causative relationship or not has not been proven yet. The evidence presented here suggests that SS controls nitrogen fixation under mild drought conditions. However, nitrogen fixation cannot be enhanced only by increasing glycolytic flux, as under these conditions nodules become oxygen limited. Abscisic acid also induces a decline in nitrogen fixation that is independent of SS. The overall results suggest the occurrence of a complex regulation of nodule nitrogen fixation involving, at least, both carbohydrate and oxygen fluxes within the nodule.
\end{abstract}

glycolytic flux / nitrogen / nodules / metabolism regulation

Résumé - Vers la connaissance de la régulation de la fixation d'azote par les nodosités des légumineuses : enseignements tirés de la sécheresse, de l'acide abscissique et de l'accroissement de la disponibilité des photo-assimilats. La fixation d'azote par les nodosités des légumineuses est très sensible à la sécheresse ainsi qu'aux autres contraintes environnementales. Il était généralement supposé que la diminution de la fixation d'azote était due à un renforcement de la barrière à la diffusion de l'oxygène dans les nodosités qui entraîne une diminution de la respiration des bactéroïdes. Cependant, il a été montré récemment que la fixation de l'azote est fortement corrélée à l'activité de la saccharose synthase (SS) des nodosités de plants soumis à la sécheresse ou à d'autres contraintes environnementales. Que cette corrélation corresponde à une relation causale ou non, n'a pas encore été prouvé. Les résultats présentés ici suggèrent que la SS peut contrôler la fixation d'azote dans des conditions de sécheresse peu sévères. Cependant, la fixation de l'azote ne peut pas être accrue seulement par l'augmentation du flux de glucides vers les nodosités, car dans ces conditions l'oxygène devient un facteur limitant. Par ailleurs, l'acide abscissique induit également une limitation de la fixation d'azote indépendante de la SS. L'ensemble des résultats expérimentaux suggère ainsi l'existence d'un système complexe de régulation de la fixation d'azote qui dépend à la fois des flux de glucides et d'oxygène dans les nodosités.

glucide / azote / nodosité / régulation du métabolisme

Communicated by Jean-Jacques Drevon (Montpellier, France)

* Correspondence and reprints

cesarai@unavarra.es 


\section{INTRODUCTION}

The $\mathrm{N}$ requirement of legumes can be met by both mineral nitrogen assimilation and symbiotic $\mathrm{N}_{2}$ fixation, and in practice nitrogen nutrition of legumes is the result of both processes. The contribution of both nitrogen sources to the total plant nitrogen is determined by the legume nitrogen requirement and mineral $\mathrm{N}$ supply, provided an effective Rhizobium symbiosis is ensured [12].

The need to develop techniques allowing optimal utilisation of natural resources for agriculture without damaging the environment, highlights the importance of legumes in a range of agricultural systems. Their impact is multifunctional, ranging from being an essential source of protein, to their capability to replenish soil depleted of nitrogen. Legumes are regarded as an integral part of many sustainable agricultural production systems.

Nitrogen fixation in nodules is a process sensitive to environmental stresses [31] and, particularly, a droughtsensitive process (see [28] and references therein), and drought is a common problem in the Mediterranean Basin. The idea that nitrogen fixing plants are more sensitive to environmental stresses than those given fertiliser nitrate is now being challenged [1, 11, 13, 24]. Early reports on the effects of drought on nitrogen fixation concluded that a lack of assimilates resulting from the reduction in shoot photosynthesis was the primary cause for its decline [21]. Finn and Brun [10] found a parallel decline in nitrogenase activity and photosynthesis. However, later reports [9] showed that nitrogen fixation is more sensitive than photosynthesis to moderate water deprivation: nitrogen fixation decreases steadily throughout the water deficiency period whilst photosynthesis decreases only slightly for the first days under drought. The mechanism by which nitrogen fixation is inhibited by water stress has been explained by a variable oxygen diffusion barrier [22, 25, 30]. Thus, the current model for nodule response to many environmental stresses, including drought, is that the stress triggers the resistance of the oxygen diffusion barrier. This is thought to provoke a decrease in the influx of oxygen, which leads to reduced bacteroid respiration and, therefore, a decline in nitrogen fixation.

Whilst it is clear that water stress causes an increase in oxygen resistance in nodules, it is unclear whether such changes are fully responsible for the decline in nitrogen fixation. If nitrogen fixation is only limited by the internal oxygen concentration of the nodules [e.g. 23], it should be fully recoverable by elevating rhizosphere $\mathrm{pO}_{2}$. However, it has been shown that nitrogen fixation in water-stressed nodules cannot be restored simply by increasing oxygen concentration [6]. However, the mechanism of such a response is not yet determined. Recently, it has been proposed that nodule metabolism may respond to the different stresses in addition to the changes in nodule permeability [6, 7]. Thus, González et al. [17] found a rapid decline of both sucrose synthase (SS) activity and protein content in soybean plants subjected to a moderate water stress. Durand et al. [9] and Djekoun and Planchon [8] showed that nitrogen fixation was more sensitive than photosynthesis to moderate water deprivation, thus SS decline does not seem to be triggered by photosynthate shortage. Moreover, sucrose is accumulated in nodules subjected to water stress [17]. Thus, it has been suggested that the impairment of sucrose metabolism within the nodule could be responsible for the nitrogen fixation decline by limiting the carbon flux for bacteroid respiration [2, 17, 19]. Gordon et al. [19] found that the decline in SS activity in response to moderate water stress was related to the down-regulation of the SS gene within one day. Also, salt and nitrate supply affect SS at the expression level. Altogether these data point to the key role of SS in the regulation of nodule metabolism. However, the signal transduction pathway that links the perception of these environmental stresses and the decline of SS activity remains unknown.

Our current model [2] suggests that sucrose synthase down-regulation will produce a parallel increase in nodule sucrose content and a depletion of substrates for bacteroid respiration and would, in turn, induce a transient accumulation of oxygen in the infected region, leading to a closure of the oxygen diffusion barrier. Both the depletion of respiratory substrates and the concomitant closure of the oxygen diffusion barrier would cause the observed decline in nitrogen fixation. Our objective in this paper is focused on trying to determine whether the correlation between sucrose synthase activity and nitrogen fixation reflects a causative relationship, and to evaluate the consequences of an increase in sucrose synthase activity on nodule metabolism and whole plant performance. This has been achieved by subjecting plants to drought, abscisic acid supply or increasing $\mathrm{CO}_{2}$ availability to plants and monitoring their effects on nitrogen fixation, nodule enzyme activities and carbon substrates concentration.

\section{MATERIALS AND METHODS}

\subsection{Plant material and treatments}

Pea seeds (Pisum sativum L. cv. Sugar snap), surfacesterilised with $\mathrm{HgCl}_{2}$, were inoculated with Rhizobium leguminosarum biovar viciae strain NLV 8. Plants were grown in $1 \mathrm{dm}^{3}$ pots, with a $2 / 1$ (by volume) mixture 
of vermiculite/perlite as the substrate, with a nutrient solution lacking nitrogen [26] in a controlled environment chamber $\left(22 / 18^{\circ} \mathrm{C}\right.$-day/night temperature, $70 \%$ relative humidity, $500 \mu \mathrm{mol} \cdot \mathrm{m}^{-2} \cdot \mathrm{s}^{-1}$ (PPF), and $15 \mathrm{~h}$ photoperiod). Plants were grown for 3 weeks and then treatments were applied for nine days, except for increased $\mathrm{CO}_{2}$ availability (see below), as follows: drought (D) was imposed by withholding water/nutrients [14] and for abscisic acid treatments (ABA), exogenous ABA $(100 \mu \mathrm{M})$ was supplied daily to the nutrient solution [16]. The increase in photoassimilate availability $\left(\mathrm{CO}_{2}\right)$ was obtained by increasing atmospheric $\mathrm{CO}_{2}$ concentration to $1000 \mu \mathrm{mol} \cdot \mathrm{mol}^{-1}$, from sowing, as described elsewhere [4]. Controls were harvested at the beginning and the end of the experimental period. Since most parameters did not change significantly during this period only the latter is shown in the present paper (C).

\subsection{Water relations and gas exchange measurements}

Leaf water potential was measured two hours after the beginning of the photoperiod using a pressure chamber (Soil Moisture Equipment, Santa Barbara, CA) [27].

Net $\mathrm{CO}_{2}$ assimilation rate was measured with a portable IRGA (LI-6200, Li-Cor, Lincoln, NE). Specific nitrogen fixation was measured as $\mathrm{H}_{2}$ evolution on intact plants, housed in the growth chamber, whose nodulated roots were sealed in an open flow-through system using an electrochemical $\mathrm{H}_{2}$ sensor (Qubit System Inc., Canada) at a flow rate of $300 \mathrm{ml} \cdot \mathrm{min}^{-1}$. Nitrogen fixation rate was calculated as total nitrogenase activity (under Ar: $\mathrm{O}_{2}(79 / 21)$ - apparent nitrogenase activity (under $\left.\mathrm{N}_{2}: \mathrm{O}_{2}(79 / 21)\right) / 3$ [4].

\subsection{Analytical determinations}

Dry weights of each plant organ (shoots, roots and nodules) were determined after drying at $70{ }^{\circ} \mathrm{C}$ for 2 days. Plant organic nitrogen was determined from these samples by Kjeldahl analysis.

For the extraction and assay of enzyme activities, nodules were homogenised in a mortar and pestle with 5 volumes of $50 \mathrm{mM}$ MOPS, $10 \%$ PVPP, $10 \mathrm{mM}$ DTT, $1 \mathrm{mM}$ EDTA, $20 \mathrm{mM} \mathrm{KCl}, 5 \mathrm{mM} \mathrm{MgCl} 2, \mathrm{pH} 7$ at $0-2{ }^{\circ} \mathrm{C}$. The homogenate was centrifuged for $30 \mathrm{~min}$ at $20000 \mathrm{~g}, 2^{\circ} \mathrm{C}$. Samples $(50 \mu \mathrm{l})$ of the supernatant were retained for phosphoenol pyruvate carboxylase (PEPC, EC 4.1.1.31) assay [17]. One $\mathrm{ml}$ aliquots were desalted by low speed centrifugation $(180 \mathrm{~g}, 1 \mathrm{~min})$ through $5 \mathrm{ml}$ columns of Bio Gel P6DG (BioRad) equilibrated with the extraction buffer (see above) without PVPP. The desalted extract was used to determine the following enzyme activities: alkaline invertase (EC 3.2.1.26), malate dehydrogenase (EC 1.1.1.37), sucrose synthase (EC 2.4.1.13) and uridine diphosphoglucose pyrophosphorylase (EC 2.7.7.9) [14].

For nodule malate and sucrose concentrations, fresh material was exhaustively extracted in 5 volumes of boiling $80 \%$ (v/v) ethanol. Ethanol soluble extracts were dried in a Turbovap LV evaporator (Zymark Corp, Hopkinton, MA) and soluble compounds were redissolved with $4 \mathrm{ml}$ of distilled water, mixed and centrifuged at $20000 \mathrm{~g}$ for $10 \mathrm{~min}$. Sucrose was measured in the supernatant enzymatically [17] and malate was also analysed in this supernatant by ion chromatography in a DX-500 system (Dionex, Salt Lake City, UT) by gradient separation with a Dionex IonPac AS11 column [15].

\subsection{Statistical analysis}

Results were examined by one-way analysis of variance. All effects discussed in this study were significant at $p \leq 0.05$ in Fisher's (protected) least significant difference (LSD) tests between means.

\section{RESULTS}

Treatments used in the present paper are likely to affect nodule and nitrogen fixation performance, but also to affect other physiological parameters. A summary of the effects caused at the whole plant level is shown in Table I. Water deficit provoked a slight decrease in leaf water potential, whilst $\mathrm{ABA}$ and the increased $\mathrm{CO}_{2}$ availability did not affect plant water status. Likewise, photosynthetic activity, at the end of the study period, was also more affected in water-stressed than in ABAtreated plants. Conversely, the increase in $\mathrm{CO}_{2}$ availability was reflected in a higher photosynthetic carbon assimilation rate. This pattern was consistent with the plant biomass, as plants grown with a higher availability of $\mathrm{CO}_{2}$ also showed an increased dry weight. The decrease in photosynthesis in water-stressed plants was reflected in plant biomass, whilst we failed to detect significant differences between control and ABA-treated plants. Variations in plant biomass were also reflected in nodule biomass, which decreased in drought-stressed plants and increased under high $\mathrm{CO}_{2}$, whilst did not vary with ABA supply.

Nitrogen fixation rates were assessed both by measuring plant nitrogen content and monitoring $\mathrm{H}_{2}$ evolution at the end of the study period. Results of plant nitrogen content closely paralleled those of plant biomass and photosynthesis. However, specific nitrogen fixation 
Table I. Physiological parameters of plants subjected to different environmental circumstances: drought (D), abscisic acid (ABA), increased $\mathrm{CO}_{2}\left(\mathrm{CO}_{2}\right)$ and their corresponding controls $(\mathrm{C})$. (N)DW denotes (nodule) dry weight. Values presented as mean \pm standard error $(n=8)$. For each parameter, numbers followed by a different letter are significantly different at $p \leq 0.05$ in a LSD test.

\begin{tabular}{|c|c|c|c|c|}
\hline & $\mathrm{C}$ & $\mathrm{D}$ & $\mathrm{ABA}$ & $\mathrm{CO}_{2}$ \\
\hline Leaf water potential (MPa) & $-0.41 \pm 0.03 \mathrm{a}$ & $-0.83 \pm 0.01 \mathrm{~b}$ & $-0.45 \pm 0.05 \mathrm{a}$ & $-0.39 \pm 0.03 \mathrm{a}$ \\
\hline Photosynthesis $\left(\mu \mathrm{mol} \mathrm{CO} \cdot \mathrm{m}^{-2} \cdot \mathrm{s}^{-1}\right)$ & $7.0 \pm 0.4 \mathrm{a}$ & $2.4 \pm 0.3 \mathrm{~b}$ & $5.7 \pm 0.4 \mathrm{c}$ & $9.1 \pm 0.6 \mathrm{~d}$ \\
\hline Plant biomass (g DW.plant $\left.{ }^{-1}\right)$ & $1.1 \pm 0.1 \mathrm{a}$ & $0.8 \pm 0.1 \mathrm{~b}$ & $1.0 \pm 0.1 \mathrm{a}$ & $1.7 \pm 0.2 \mathrm{c}$ \\
\hline Nodule biomass (mg NDW.plant ${ }^{-1}$ ) & $70 \pm 5 \mathrm{a}$ & $58 \pm 5 b$ & $67 \pm 3 a$ & $100 \pm 5 c$ \\
\hline Plant nitrogen content $\left(\mathrm{mg} \mathrm{N} \cdot\right.$ plant $\left.^{-1}\right)$ & $35.5 \pm 4.2 \mathrm{a}$ & $28.5 \pm 2.4 \mathrm{~b}$ & $33.2 \pm 3.2 \mathrm{ab}$ & $40.0 \pm 4.2 \mathrm{c}$ \\
\hline Specific nitrogen fixation $\left(\mu \mathrm{mol} \mathrm{N}{ }_{2} \cdot \mathrm{g}^{-1} \mathrm{NDW} \cdot \mathrm{min}^{-1}\right)$ & $0.29 \pm 0.02 \mathrm{a}$ & $0.08 \pm 0.01 \mathrm{~b}$ & $0.09 \pm 0.01 \mathrm{~b}$ & $0.30 \pm 0.02 \mathrm{a}$ \\
\hline
\end{tabular}

Table II. Nodule enzyme activities $\left(\mu \mathrm{mol}\right.$ NADH $\cdot \mathrm{mg}^{-1}$ protein $\left.\cdot \mathrm{min}^{-1}\right)$. Values represent mean \pm standard error $(n=8)$. For each parameter, numbers followed by a different letter are significantly different at $p \leq 0.05$ in a LSD test.

\begin{tabular}{lcccc}
\hline & $\mathrm{C}$ & $\mathrm{D}$ & $\mathrm{ABA}$ & $\mathrm{CO}_{2}$ \\
\hline Alkaline invertase & $0.21 \pm 0.02 \mathrm{a}$ & $0.18 \pm 0.01 \mathrm{a}$ & $0.17 \pm 0.01 \mathrm{a}$ & $0.19 \pm 0.02 \mathrm{a}$ \\
Sucrose synthase & $0.14 \pm 0.01 \mathrm{a}$ & $0.03 \pm 0.03 \mathrm{~b}$ & $0.12 \pm 0.02 \mathrm{a}$ & $0.18 \pm 0.01 \mathrm{c}$ \\
UDP-glucose pyrophosphorylase & $1.13 \pm 0.04 \mathrm{a}$ & $0.67 \pm 0.01 \mathrm{~b}$ & $1.08 \pm 0.10 \mathrm{a}$ & $1.55 \pm 0.15 \mathrm{c}$ \\
Phosphoenol pyruvate carboxylase & $0.22 \pm 0.02 \mathrm{a}$ & $0.09 \pm 0.04 \mathrm{~b}$ & $0.19 \pm 0.02 \mathrm{a}$ & $0.26 \pm 0.01 \mathrm{c}$ \\
Malate dehydrogenase & $17.1 \pm 1.1 \mathrm{a}$ & $18.2 \pm 3.3 \mathrm{a}$ & $16.3 \pm 0.7 \mathrm{a}$ & $17.9 \pm 1.8 \mathrm{a}$ \\
\hline
\end{tabular}

showed a quite different pattern with no significant differences between control and high- $\mathrm{CO}_{2}$ nodules and decreased nitrogen fixation in water-stressed and $\mathrm{ABA}-$ treated nodules.

Activities of enzymes of carbon metabolism were assessed in nodules of the four treatments (Tab. II). Alkaline invertase and malate dehydrogenase did not vary under any treatment. On the contrary, sucrose synthase, UDP-glucose pyrophosphorylase and PEPC showed the same pattern: they increased in high $\mathrm{CO}_{2}$ and decreased in water stress, whilst their activity did not vary with $A B A$ supply.

These changes in the carbon-metabolising enzyme activities led to some changes in the nodule concentration of sucrose and malate and the relationship between them (Fig. 1). Thus, sucrose concentration increased in nodules subjected to drought and high $\mathrm{CO}_{2}$. However, malate concentration changed in both treatments with opposite trends: whilst malate concentration dramatically decreased in nodules under drought, it increased in high $\mathrm{CO}_{2}$ by the same proportion as that of the above-mentioned sucrose. Sucrose and malate concentration of ABA-treated nodules did not differ significantly from those of control plants. Accordingly, the sucrose/malate molar ratio was the same for control and high $\mathrm{CO}_{2}$ (1.6 $\mu \mathrm{mol}$ sucrose $\mu \mathrm{mol}^{-1}$ malate), slightly lower, although not statistically significant, for ABA-treated

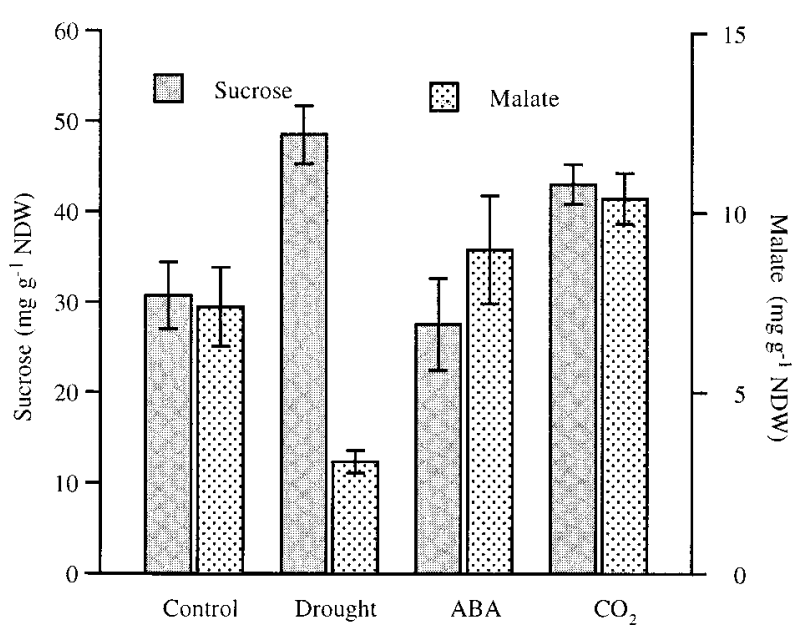

Figure 1. Effect of water stress, abscisic acid and increased atmospheric $\mathrm{CO}_{2}$ on sucrose and malate concentration of pea nodules. Results are means $\pm \mathrm{SE}(n=8)$.

nodules (1.2) and dramatically higher (6.2) for waterstressed nodules. 


\section{DISCUSSION}

Ultimately, nodule nitrogen fixation depends on the supply of sucrose delivered from the phloem, as in other sink tissues [3]. This sucrose may be hydrolysed by either sucrose synthase (SS) or alkaline invertase (AI), and follow the glycolytic pathway to provide energy and carbon skeletons for bacteroid respiration and ammonia assimilation. Environmental alterations may provoke pleiotropic effects on plant physiology. Thus, treatments used in the present paper may affect plant water status and photosynthesis leading to changes in plant biomass and allocation (Tab. I). This can be particularly relevant as these variations may include changes in nodule biomass. Indeed, the negative effect of environmental stresses on nitrogen fixation may be due to three different responses: effects on the infection of legumes by rhizobia, effects on nodule growth and development and, finally, direct effects on nodule functioning. As stated in the introduction, the objective of the present paper is addressed to the latter. Specific nitrogen fixation was impaired by drought and $\mathrm{ABA}$ supply, but high $\mathrm{CO}_{2}$ availability, although it promoted an increase in nodule biomass and plant nitrogen content, did not enhance specific nitrogen fixation.

Activities of enzymes of carbon metabolism were assessed in nodules of the four treatments. None of these treatments affected alkaline invertase or malate dehydrogenase. The latter seems to be well in excess and, therefore, is little affected by a changing environment [4]. On the contrary, sucrose synthase, UDP-glucose pyrophosphorylase and PEPC showed the same pattern: they increased in high $\mathrm{CO}_{2}$ and decreased in water stress, whilst their activity did not vary with ABA supply. This data provides further support to the suggestion [18] that SS/UDPG is the key pathway in nodules to respond to changes in their environment and strongly suggests that in nodules of plants grown at supra-ambient $\mathrm{CO}_{2}$, there exists an increased carbon flux, whilst this is impaired under drought and not affected by ABA.

Evidence obtained so far shows that down-regulation of sucrose synthase leads to sucrose accumulation [14, $17,19]$, which has been taken as an indication of substrate shortage for bacteroid respiration. However, this situation could be derived from a direct effect of drought on the oxygen diffusion barrier and the decreased carbon utilisation by bacteroids may cause the down-regulation of SS. If the latter is true, one may expect an increase in malate concentration. Indeed, it has been suggested [5] that glycolytic flux may be adjusted to nitrogenase activity, as the main carbon sink in nodules, in response to detopping and replacement of air by argon. However, malate concentration in nodules was reduced when water potential declined, while sucrose actually increased, therefore increasing the sucrose/malate ratio and providing further support for the idea that carbon flux is impaired under water stress, prior to the decrease in nitrogenase sink strength.

This situation seems to be different in the remaining treatments. ABA-treated nodules also experienced a decline in nitrogen fixation (Tab. I). However, activities of carbon-metabolising enzymes and the sucrose and malate levels are not significantly different from control nodules, suggesting that in this treatment carbon flux is not involved in the regulation of nitrogen fixation. It has been recently shown that this decline is not due either to any shortage of photoassimilate availability, but to direct effects on a leghemoglobin/oxygen-related control of nitrogen fixation [16]. The enhancement of carbonmetabolising enzymes at supra-ambient $\mathrm{CO}_{2}$ levels was consistent with an increase in both sucrose and malate, although without altering this balance, suggesting the occurrence of an increased carbon flux, which fails to increase nitrogen fixation.

The interpretation of these results is consistent with the occurrence of at least two different control pathways within nodules in response to changes in the environment involving a double carbon/oxygen switch (Fig. 2). When either of them decreases, this leads to a decline in nitrogen fixation; whilst the increase in either of them

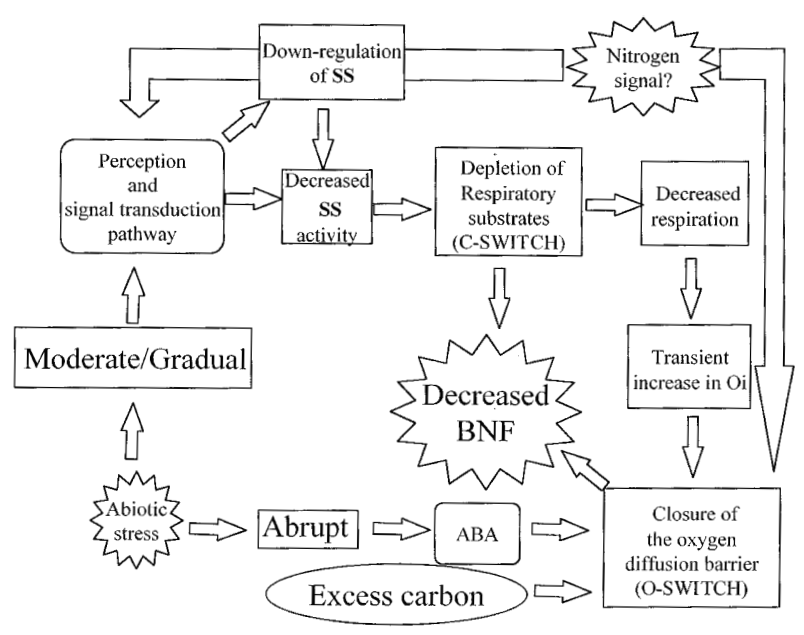

Figure 2. Suggested model for the effects of carbon and oxygen flux on nodule nitrogen fixation. The O-switch would also operate under conditions of excess carbon availability. As discussed in the text, nitrogen signals may trigger the decrease of glycolytic flux and/or the closure of the oxygen diffusion barrier. 
fails to enhance nitrogen fixation as the remaining factor becomes limiting. Thus, moderate and gradual environmental stresses would trigger a down-regulation of SS and the lack of respiratory substrates for bacteroid respiration, whilst abrupt stresses would involve an Lb/oxygen-related control of nitrogen fixation, that, at least in some environmental circumstances, may be triggered by ABA. Moreover, an ample supply of carbohydrate would also fail to enhance nitrogen fixation, because of the occurrence of the oxygen-switch. Whether these controls also operate under normal conditions, and their relationships with the suggested whole plant control based on the nitrogen status, deserves further investigation.

Indeed, the precise nature of the signal that links the perception of the environment alteration and the signal transduction pathway leading to the down-regulation of sucrose synthase or the closure of the oxygen diffusion barrier remains to be elucidated. However, it cannot be disregarded that factors, such as the $\mathrm{N}$ plant and/or nodule status, may also be involved in such a regulation, as discussed elsewhere [20,29]. Nodules may provide an excellent model for studying carbon/nitrogen/oxygen interactions in plants and this knowledge may be of primary interest for agriculture.

Acknowledgements: The authors thank Gustavo Garijo, Amelia Aguilar and Pablo Cabrerizo for technical assistance. Loli Gálvez was the holder of a grant from the Spanish Ministry of Education (Plan F.P.U.). Seeds were kindly supplied by Bonduelle (Milagro, Spain). This work was supported by DGESIC (PB98-0545).

\section{REFERENCES}

[1] Antolín M.C., Yoller J., Sánchez-Díaz M., Effects of temporary drought on nitrate-fed and nitrogen-fixing alfalfa plants, Plant Sci. 107 (1995) 159-165.

[2] Arrese-Igor C., González E.M., Gordon A.J., Minchin F.R., Gálvez L., Royuela M., Cabrerizo P.M., Aparicio-Tejo P.M., Sucrose synthase and nodule nitrogen fixation under drought and other environmental stresses, Symbiosis 27 (1999) 189-212.

[3] Avigad G., Sucrose and other dissacharides, in: Loewus F.A., Tanner W. (Eds.), Encyclopedia of Plant Physiology (New Series), Vol. 13A, Springer-Verlag, Berlin, 1982, pp. 216-347.

[4] Cabrerizo P.M., González E.M., Aparicio-Tejo P.M., Arrese-Igor C., Continuous $\mathrm{CO}_{2}$ enrichment leads to increased nodule biomass, carbon availability to nodules and activity of carbon-metabolising enzymes but does not enhance specific nitrogen fixation in pea, Physiol. Plant. 113 (2001) 33-40.

[5] Curioni P.M.G., Hartwig U.A., Nösberger J., Schuller K.A., Glycolytic flux is adjusted to nitrogenase activity in nodules of detopped and argon-treated alfalfa plants, Plant Physiol. 119 (1999) 445-453.
[6] Diaz del Castillo L., Hunt S., Layzell D.B., The role of oxygen in the regulation of nitrogenase activity in droughtstressed soybean nodules, Plant Physiol. 106 (1994) 949-955.

[7] Diaz del Castillo L., Layzell D.B., Drought stress, permeability to $\mathrm{O}_{2}$ diffusion and the respiratory kinetics of soybean root nodules, Plant Physiol. 107 (1995) 1187-1194.

[8] Djekoun A., Planchon C., Water status effect on dinitrogen fixation and photosynthesis in soybean, Agron. J. 83 (1991) 316-322.

[9] Durand J.L., Sheehy J.E., Minchin F.R., Nitrogenase activity, photosynthesis and nodule water potential in soya bean plants experiencing water deprivation, J. Exp. Bot. 38 (1987) 311-321.

[10] Finn G.A., Brun W.A., Water stress effects on $\mathrm{CO}_{2}$ assimilation, photosynthate partitioning, stomatal resistance, and nodule activity in soybean, Crop Sci. 20 (1980) 431-434.

[11] Frechilla S., González E.M., Royuela M., Minchin F.R., Aparicio-Tejo P.M., Arrese-Igor C., Source of nitrogen nutrition (nitrogen fixation or nitrate assimilation) is a major factor involved in pea response to moderate water stress, J. Plant Physiol. 157 (2000) 609-617.

[12] George T., Singleton P.W., Nitrogen assimilation traits and dinitrogen fixation in soybean and common bean, Agron. J. 84 (1992) 1020-1028.

[13] González A., González-Murua C., Royuela M., Influence of imazethapyr on Rhizobium growth and its symbiosis with pea (Pisum sativum), Weed Sci. 44 (1996) 31-37.

[14] González E.M., Aparicio-Tejo P.M., Gordon A.J., Minchin F.R., Royuela M., Arrese-Igor C., Water-deficit stress effects on carbon and nitrogen metabolism of pea nodules, J. Exp. Bot. 49 (1998) 1705-1714.

[15] González E.M., Cabrerizo P.M., Royuela M., AparicioTejo P.M., Arrese-Igor C., Nitrate reduction in tendrils of semileafless pea, Physiol. Plant. 111 (2001) 329-335.

[16] González E.M., Gálvez L., Arrese-Igor C., Abscisic acid induces a decline in nitrogen fixation that involves leghaemoglobin, but is independent of sucrose synthase activity, J. Exp. Bot. 52 (2001) 285-293.

[17] González E.M., Gordon A.J., James C.L., Arrese-Igor C., The role of sucrose synthase in the response of soybean nodules to drought, J. Exp. Bot. 46 (1995) 1515-1523.

[18] Gordon A.J., Carbon metabolism in the legume nodule, in: Pollock C.J., Farrar J.F., Gordon A.J. (Eds.), Carbon partitioning within and between organisms, BIOS Scientific Publishers, Oxford, 1992, pp. 133-162.

[19] Gordon A.J., Minchin F.R., Skøt L., James C.L., Stress-induced declines in soybean $\mathrm{N}_{2}$ fixation are related to nodule sucrose synthase activity, Plant Physiol. 114 (1997) 937-946.

[20] Hartwig U.A., The regulation of symbiotic $\mathrm{N}_{2}$ fixation: a conceptual model of $\mathrm{N}$ feedback from the ecosystem to the gene expression level, Persp. Plant Ecol. Evol. Syst. 1 (1998) 91-119.

[21] Huang C., Boyer J.S., Vanderhoef L.N., Limitation of acetylene reduction (nitrogen fixation) by photosynthesis in 
soybeans having low water potentials, Plant Physiol. 56 (1975) 228-232.

[22] Hunt S., Layzell D.B., Gas exchange of legume nodules and the regulation of nitrogenase activity, Annu. Rev. Plant Physiol. Plant Mol. Biol. 44 (1993) 483-511.

[23] Layzell D.B., Hunt S., Palmer, G.R., Mechanism of nitrogenase inhibition in soybean nodules. Pulse-modulated spectroscopy indicates that nitrogenase activity is limited by $\mathrm{O}_{2}$, Plant Physiol. 92 (1990) 1101-1107.

[24] Lodeiro A.R., González P., Hernández A., Balagué L., Favelukes G., Comparison of drought tolerance in nitrogen-fixing and inorganic nitrogen-grown common beans, Plant Sci. 154 (2000) 31-41.

[25] Minchin F.R., Witty J.F., Sheehy J.E., Müller M., A major error in the acetylene reduction assay: decreases in nodular nitrogenase activity under assay conditions, J. Exp. Bot. 34 (1983) 641-649.
[26] Rigaud J., Puppo A., Indole-3-acetic catabolism by soybean bacteroids, J. Gen. Microbiol. 88 (1975) 223-228.

[27] Scholander P.F., Hammel H.T., Bradstreet E.D., Hemmingsen E.A., Sap pressure in vascular plants, Science 148 (1965) 339-346.

[28] Serraj R., Sinclair T.R., Purcell L.C., Symbiotic $\mathrm{N}_{2}$ fixation response to drought, J. Exp. Bot. 50 (1999) 143-155.

[29] Serraj R., Vadez V., Sinclair T.R., Feedback regulation of symbiotic $\mathrm{N}_{2}$ fixation under drought stress, Agronomie 21 (2001) 621-626.

[30] Sheehy J.E., Minchin F.R., Witty J.F., Biological control of the resistance to oxygen flux in nodules, Ann. Bot. 52 (1983) 565-571.

[31] Zahran H.H., Rhizobium-legume symbiosis and nitrogen fixation under severe conditions and in an arid climate, Microbiol. Mol. Biol. Rev. 63 (1999) 968-989.

To access this journal online: www.edpsciences.org 